\title{
DRACULA IRMELINAE, A NEW SPECIES IN THE SUBTRIBE PLEUROTHALLIDINAE (ORCHIDACEAE) FROM THE WESTERN ANDES OF COLOMBIA
}

\author{
Nicolás Peláez ${ }^{1,2,7}$, Gary E. Meyer ${ }^{3,7}$, Ubiel Rendon-Jaramillo ${ }^{4}$, \\ Juan David Fernández ${ }^{5}$, Norberto López-Álvarez ${ }^{5}$ \& Luis A. Mazariegos H., 4,6,7 \\ ${ }^{1}$ California Institute of Technology, Department of Biology and Bioengineering, \\ 1200 E. California Blvd., MC 114-96 Pasadena, CA 91125, U.S.A. \\ ${ }^{2}$ Howard Hughes Medical Institute (HHMI), Hanna H. Gray Fellows Program, U.S.A. \\ ${ }^{3}$ San Francisco Orchid Society (SFOS), San Francisco, CA, U.S.A. \\ ${ }^{4}$ Mesenia - Paramillo Nature Reserve, Antioquia, Colombia \\ ${ }^{5}$ Fundación Jardín Botánico Joaquin Antonio Uribe (JAUM), Medellin, Colombia \\ ${ }^{6}$ The Hummingbird Conservancy, Jardín, Antioquia, Colombia
}

${ }^{7}$ Corresponding authors: nicopel@caltech.edu, garymeyerphd@yahoo.com, lamh@bioconservancy.org

\begin{abstract}
A new species of Dracula (Pleurothallidinae: Orchidaceae) from Colombia is described, honoring Irmelin Indenbirken, mother of the actor and philanthropist Leonardo DiCaprio. Dracula irmelinae is phenotypically most similar to D. verticulosa, but differs in having larger and wider sepals that form a smoothly curved semicircular mentum behind the lip, an indumentum with dark red internal and external maculae and dense long pubescence on the internal sepal surfaces and bases of the tails. The geographic distributions of the two species also differ, with the new species being restricted to a small area in the western Cordillera of Colombia. The conservation status of the new taxon is assessed as Endangered (EN) according to the International Union for Conservation of Nature (IUCN) criteria.
\end{abstract}

Resumen. Una nueva especie de Dracula (Pleurothallidinae: Orchidaceae) en honor a Irmelin Indenbirken, madre del actor y filántropo Leonardo DiCaprio, es descrita a continuación. Dracula irmelinae es fenotípicamente más similar a $D$. verticulosa, pero se diferencia por tener sépalos más largos y anchos que forman un mentum semicurcular, suavemente curvado detrás del labelo, un indumento con máculas rojas oscuras en las caras internas y externas de los sépalos, y una pubescencia densa y larga en la cara interna de los sépalos y la base de las caudas. La distribución geográfica de las dos especies también difiere dado que la nueva especie está restringida a un área pequeña de la cordillera occidental de Colombia. El estado de conservación del nuevo taxón es evaluado y se reporta como En Peligro (EN, por sus siglas en inglés) usando los criterios de la Unión Internacional para la Conservación de la Naturaleza (UICN).

Key words / Palabras clave: Colombia, Cordillera Occidental, Dracula, endangered species, especies amenazadas, Pleurothallidinae, Western Andes

Introduction. The genus Dracula Luer contains approximately 134 species (Karremans 2016). Since their original discovery in the western Andes of Colombia in the nineteenth century and their initial

circumscription in a section of genus Masdevallia Ruiz \& Pav., species of Dracula have been sought after due to their horticultural value. The genus has been the subject of several monographs (Luer, Escobar \&

Author contributions: NP, GEM, and LAMH contributed equally to this work. Study conception and design, manuscript preparation (drafting text and figures): NP, GEM and LAMH. Data acquisition (field \& lab/herbarium): NP, GEM, LAMH and U.R-J Analysis and interpretation of data: NP, GEM and LAMH. Orchid taxonomy (species description, diagnosis): GEM, NP. Images in figures: Field photographs: GEM, LAMH, NP; Herbarium Specimens: JDF, NL-Á. Botanical Drawing: NP. Specimen collection and/or preparation: JDF, NL-Á, LAMH, GEM, NP. Survey natural populations \& conservation status at different sites: U.R-J, LAMH, GEM, NP. IUCN categorization: NP, GEM and LAMH. Manuscript revisions: NP 
Dalström 1988, 1989, 1990, 1991, 1992, 1993, 1994, Luer 1993). New species and a few natural hybrids are still being described even from localities that have undergone significant botanical exploration (Peláez et al. 2009, Doucette 2011, Zambrano \& Solano-Gómez 2011, Doucette 2012, Luer \& Thoerle 2012, Meyer, Baquero \& Cameron 2012, Baquero 2013, Baquero \& Meyer 2014, Cavestro \& Fernandez 2016). Extensive destruction and fragmentation of native cloud forest habitats for agriculture and mining in the Andes, as well as poaching for ex-situ cultivation, have contributed to the decline of populations of multiple species of Dracula, especially in cases in which the taxa have reduced geographic distribution (GEM and NP, pers. observ., Calderón et al. 2007). For example, Colombia harbors about half (55.2\%) of the Dracula species known to date (74 sp), out of which 13 species (17.5\%) have been listed as Endangered (EN) and 33 species (24.6\%) as Vulnerable (VU) using International Union for Conservation of Nature (IUCN) criteria (Calderón et al. 2007). Formal description of new taxa precedes detailed biological studies on their structure, physiology, ecology, evolution, and in situ conservation. Here we describe Dracula irmelinae, a new species found at the Mesenia - Paramillo nature reserve (MPNR), a private preserve located in the western Cordillera of Colombia. Dracula irmelinae is vegetatively and florally most similar to $D$. verticulosa Luer \& R.Escobar, a species known only from the Central Cordillera of Colombia, further south in the Valle del Cauca province. We characterize the conservation status of this new taxon using IUCN criteria and present notes on its taxonomy, biology and natural history.

Dracula irmelinae N.Peláez, Gary Mey. \& L.Mazariegos , sp. nov. (Fig. 1-3)

TYPE: Colombia. Department of Antioquia: municipality of Jardín, La Mesenia village, found in cloud forests of the Mesenia-Paramillo nature reserve. The holotype was collected by the authors on May 14th, 2019, JDF-078 and is composed of three crossreferenced parts derived from the same individual, labeled as Parts 1-3 in the corresponding specimens [Part 1: JAUM \#083541 (dried plant), Part 2: JAUM \# 083542 (dried flower), and Part 3: JAUM \# 083541, (flower in spirit!)]. Figures 3A-B correspond to the dried holotype specimen (Parts 1-2); the flower in spirit (Part 3) is not shown. Precise elevation above sea level and other geographic information is provided in the herbarium specimens and will not be reported here (see below).

Diagnosis: Dracula irmelinae is vegetatively and florally most similar to Dracula verticulosa Luer \& Escobar due to sharing with the latter most of the floral and vegetative traits, including the plant habit, leaf blade shape, flower morphology and structure of specific flower parts such as the shape of the lateral petals and lip, the epichile aspect ratios and concavity, and the branching pattern and morphology of the lip lamellae. However, D. irmelinae can be morphologically distinguished from $D$. verticulosa by having larger and wider sepals that form a deep, semicircular, smoothly curved mentum (vs. a deep, acutely angled mentum) behind the lip, sepal indumentum containing dark red maculae internally and externally (vs externally purple-brown and internally light greenish-brown to light yellow indumentum), and long and dense pubescence on the distal internal sepal surfaces and bases of the tails (vs short and dense pubescent indumentum), and usually descending (vs usually erect) inflorescence axes.

Plant epiphytic, large, caespitose, up to $40 \mathrm{~cm}$ long. Roots coarse. Ramicauls erect, enclosed by $2-3$ loose, consecutive tubular sheaths, 4-6 cm long. Leaf erect, carinate, thinly coriaceous, narrowly elliptical, apex acute, narrowing gradually into a conduplicate subpetiolate base, $27-38 \mathrm{~cm}$ long including the petiole, $2-3 \mathrm{~cm}$ at the widest. Inflorescence successively several flowered, from the base of the ramicaul, breaking through the basal bract, then usually descending to occasionally lateral; peduncles dark green speckled in brown, subverrucose, with several green-brown tubular bracts up to $19 \mathrm{~mm}$ long; pedicel green to brown, verrucose, up to $4 \mathrm{~cm}$ long. Ovary green to brown, smooth on the outside surface, without costae, with 6 red-brown furrows running the length of the ovary, $8-10 \times 3-5 \mathrm{~mm}$. Sepals off-white and covered externally and internally with red-brown maculae that increase in density towards the center, densely long pubescent within, suborbicular, basally connate to form a deep, prolonged and smooth semicircular mentum covering the entire extension behind the lip, 

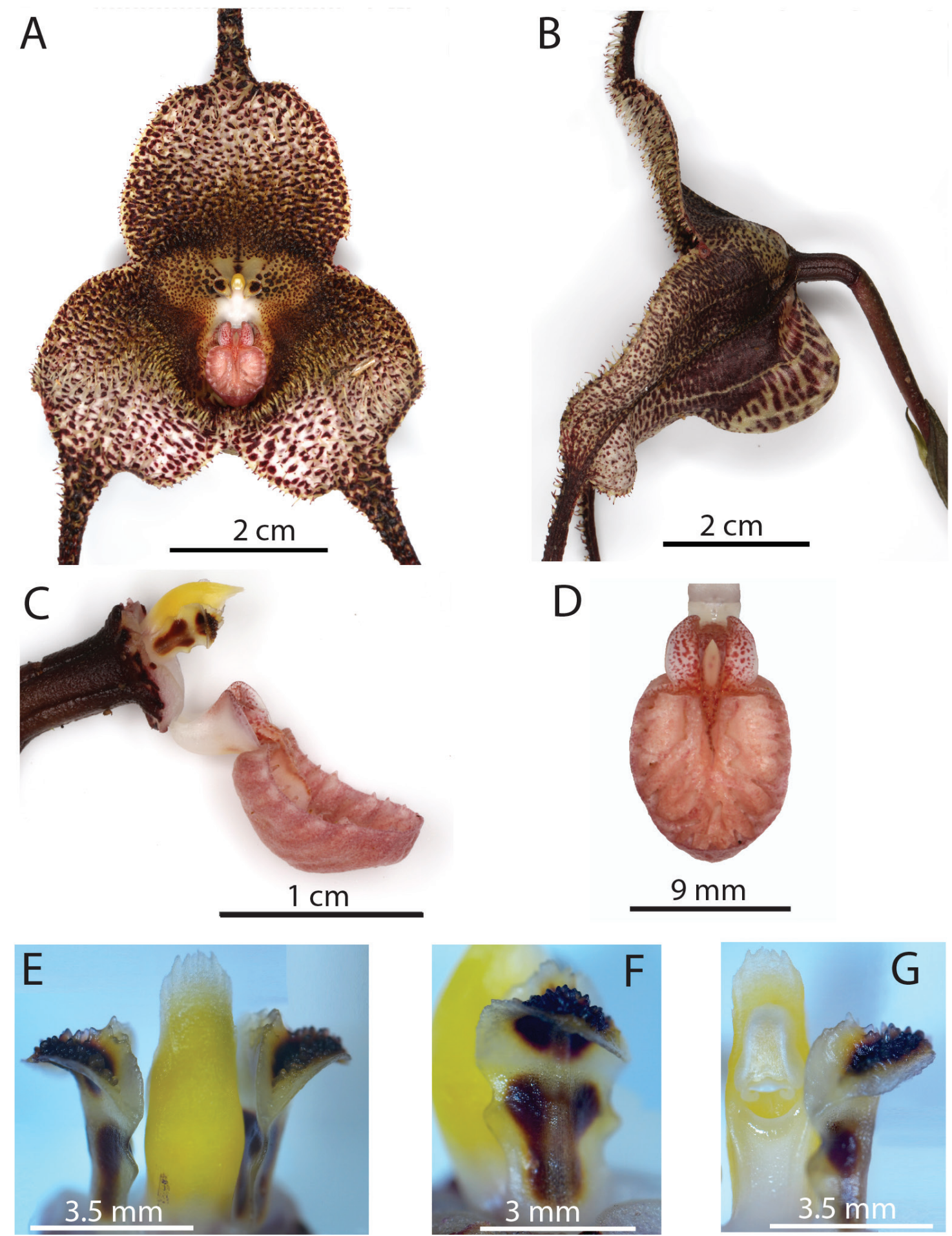

Figure 1. Flower of Dracula irmelinae N.Peláez \& Gary Mey. \& L.Mazariegos. A-B. Flower (frontal and lateral views). C. Ovary, column, petals and lip (side view). D. Lip (frontal view). E-G. Petals and column (dorsal, lateral and ventral views respectively). All specimens were collected in the wild by the authors. Photographs by L. Mazariegos. 


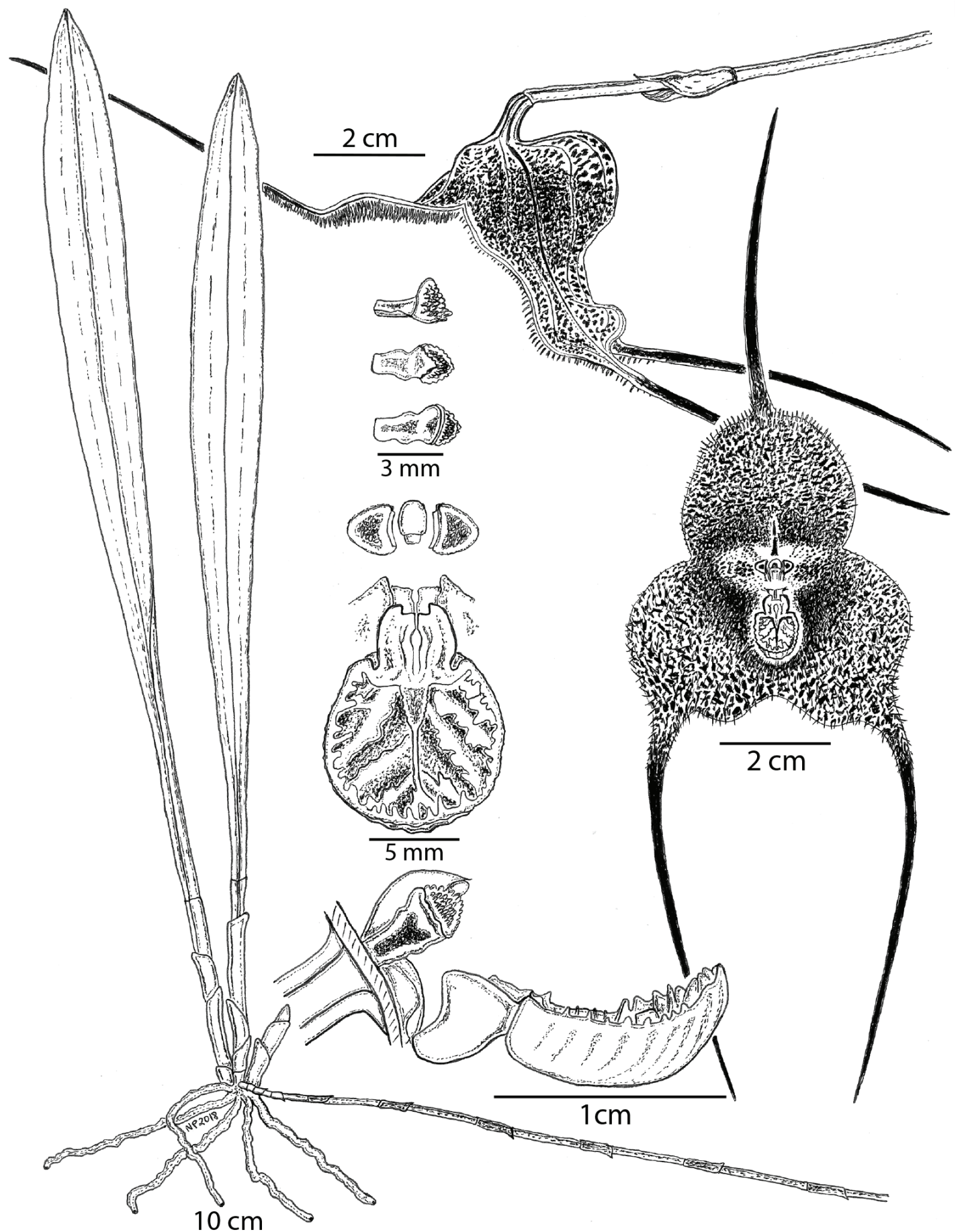

Figure 2. Botanical illustration of Dracula irmelinae N.Peláez \& Gary Mey. \& L.Mazariegos. Illustration was drawn from material photographed by the authors in the natural habitat of the species at Mesenia - Paramillo Nature Reserve. Illustration was prepared by Nicolás Peláez using specimens shown in figures 1-4 and 5 (panels A-C) and JAUM vouchers and \#083541, \#83542 and \#83541. 

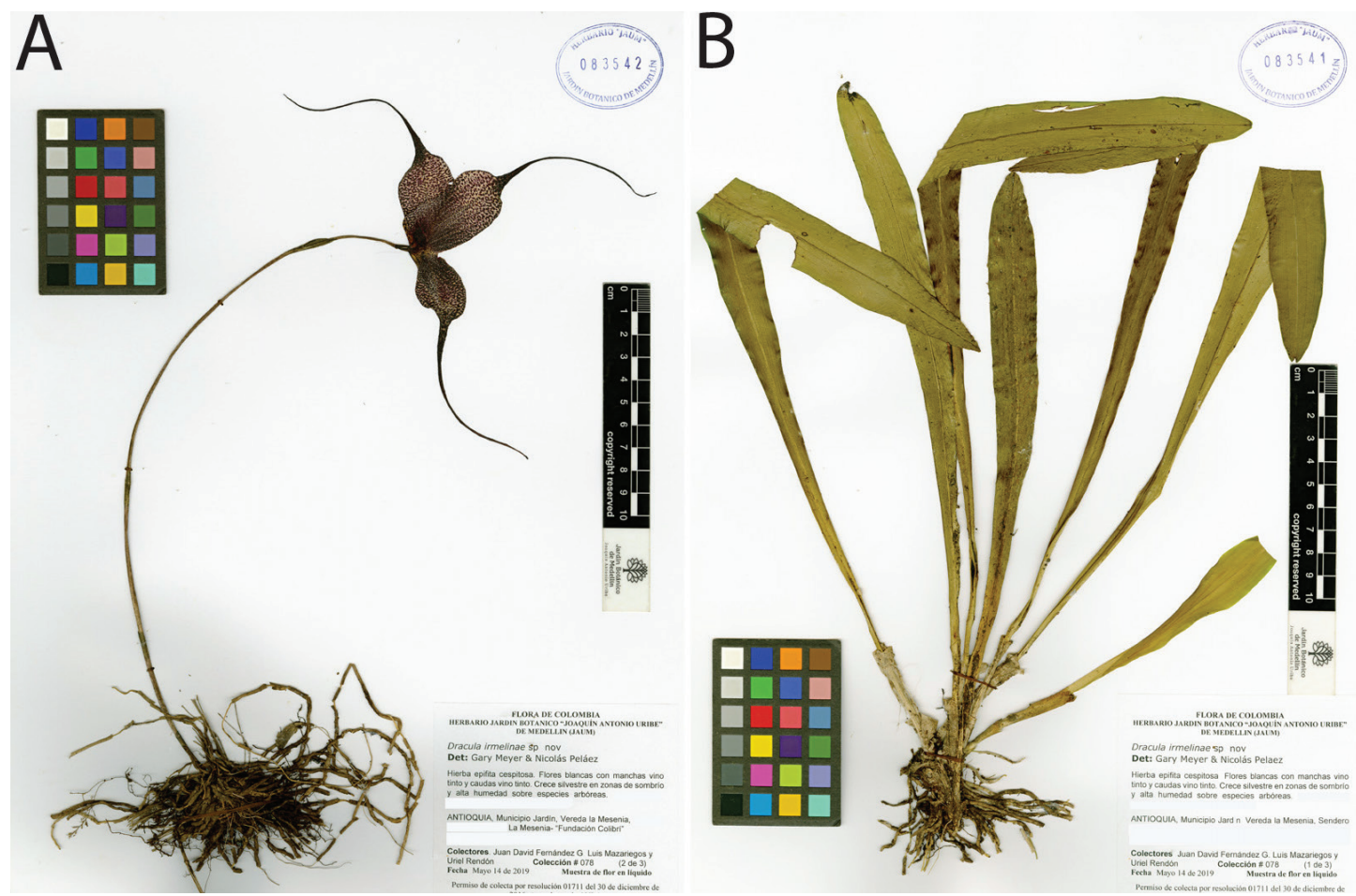

Figure 3. Holotype (Parts 1-2: dry specimen) of Dracula irmelinae N.Peláez \& Gary Mey. \& L.Mazariegos. Parts 1 and 2 of the Type specimen deposited at the JAUM herbarium: A. Flower and rhizome (Part 1), B. Plant (Part 2). Part 3 (Flower in spirit) is not shown. Photographs by N. López-Álvarez.

connate forming a prolonged synsepal that gradually flattens creating a wide open flower. Dorsal sepal $30-40 \times 25-30 \mathrm{~mm}$ excluding the tail, connate to the lateral sepals for $12-18 \mathrm{~mm}$, with the dark reddishpurple dorsal tail $5-10 \mathrm{~cm}$ in length. Lateral sepals $30-50 \times 23-33 \mathrm{~mm}$ excluding the tails, connate at the base for $40 \mathrm{~mm}$ and forming a deep, angled, whitish mentum with sparse, coarse red-brown spotting, and a 5-9 cm long reddish-purple tail continuing from the midline of each lateral sepal. Petals cartilaginous, oblong, bivalvate, stalks dark red to brown centrally and white at the margins, apex with dark brown verrucosities between the two valves, white and smooth at the margins, in close approximation to the column, $4 \mathrm{~mm}$ long $\times 3 \mathrm{~mm}$ wide at the apex. Lip spatulate, 12 $\mathrm{mm}$ long $\times 9 \mathrm{~mm}$ wide, $3 \mathrm{~mm}$ deep, articulated with the column, clearly demarcated into a hypochile and epichile; hypochile $5 \times 3 \mathrm{~mm}$, white, suffused with pink blotches, ovate, each lateral margin elaborated into a smooth rounded upwardly projecting ala, central cleft bordered by a second pair of minor alae tapering into forward-pointing projections, with a hypochile channel running medially along the adaxial surface and ending in an elongated, tapered callus that continues into $1 / 3$ to $1 / 2$ of the midline ridge of the epichile; epichile white heavily suffused with pink and orange spots, concave, semiorbicular, joined to the hypochile at a $30^{\circ}$ angle along a base $3-4 \mathrm{~mm}$ wide, with a central prominent ridge continuing from the termination of the hypochile channel that branches usually twice bilaterally and flattens into the floor of the hypochile before reaching the margin, flanked by two main broken carinae that flatten and rise multiple times and branch 3-4 times, margin non-involute, smooth externally but internally denticulate with approximately 20-24 sharp ridges arising abruptly from the epichile floor. Column white at base, yellow on the adaxial surface, semiterete, $5 \times 2$ $\mathrm{mm}$; column foot $2 \mathrm{~mm}$ long. Anther cap white. Pollinia yellow, $0.7 \mathrm{~mm}$ long. Figure 1 (flower), 2 (botanical drawing) and 3 (holotype Parts 1-2 out of 3 - dried flower and plant) illustrate the vegetative and floral morphology and details of the parts of D. irmelinae. 
PARATYPE: Dried plant and flower of D. irmelinae collected by the authors at the same location at similar elevation from a different individual than the holotype, May 14th 2019, JDF-079 (JAUM \# 083543) (not shown).

The description of new orchid species endemic to small geographic areas has in some cases triggered illegal over-collection and reduction in population sizes that have brought the new taxa close to extinction in the wild (Averyanov et al. 2014). To prevent poaching of Dracula irmelinae, we will not provide elevation or precise geographic data in this publication. Altitude and coordinate data are available in the corresponding specimens deposited at JAUM.

Dracula Verticulosa: Cultivated living specimens from Colomborquideas Ltda of D. verticulosa (Fig. 5 ) were used for comparison with $D$. irmelinae. A corresponding specimen was deposited at JAUM. Dracula verticulosa: Valle del Cauca, Between Costa Rica and Ginebra, 1800-1900, Collected by J.L. Aguirre in 1989, bloomed at Colomborquídeas, August 2016. Specimen prepared by N. Peláez and L. Mazariegos (NPR0292, JAUM \#081990).

Eponymy: The name Dracula irmelinae is in honor of Irmelin Indenbirken, the mother of the actor and philanthropist Leonardo DiCaprio, and constitutes an acknowledgement of DiCaprio's dedication to the longterm health and well-being of all of Earth's inhabitants. Leonardo DiCaprio supports conservation efforts at the Mesenia-Paramillo nature reserve through donations to SavingNature, a conservation organization working to increase the survival of threatened species through reforestation and reconnection of fragmented forests.

ECOLOGY: Little is still known about the ecology of Dracula irmelinae. Individuals of the species have been usually found growing as isolated adult plants, separated by hundreds of meters, or aggregated, forming small to medium sized clusters (usually $\mathrm{n}<20$ ) composed of siblings and a few adult plants (Fig. 4A and inset). Individuals usually grow as epiphytes in moderately to relatively well illuminated areas of the forest, sometimes $8-10 \mathrm{~m}$ above the ground, on the trunks and branches of large trees in forests in which Quercus L. are a dominant element of the flora. Initial field observations suggest plants usually synchronize their blooming, flowering more frequently in the wet season, which usually corresponds to February to April and October to December. Sporadic flowering is also observed in between these two blooming peaks. Flowers are visited by flies of the Drosophilidae family (Fig. 4C). It is therefore expected that the species uses a pollination mechanism based on chemical, morphological and visual deception described for other species of Dracula (Endara et al. 2010, Policha et al. 2016, Policha et al. 2019).

History, taxonomic notes and cultivation. Dracula irmelinae was first photographed in situ by nature guides in the Farallones de Citará before 2015. At the time of the first two observations, the security situation and accessibility of the sites precluded in situ observation by the authors. Additional individuals photographed by orchidologists near Jardín had been misidentified as D. verticulosa. Robust populations at the MPNR were originally observed by GEM and UR-J in February 2015. GEM, UR-J, and LAMH returned in November 2015 to further document these populations. Additional field observations related to the geographic distribution, habitat, and comparative morphology have been made by all authors since 2015 .

Among the known species of Dracula, D. irmelinae is phenotypically more similar to $D$. verticulosa, since it shares with the latter taxon a similar plant habit and leaf blade morphology, as well as an overall similar flower shape, lip and petal morphology. However, the new taxon differs from $D$. verticulosa in multiple traits. First, in $D$. irmelinae the indumentum features long pubescence and maculate red pigmentation on the sepals (Fig. 5A-F). Second, in D. irmelinae the bases of the lateral sepals form a deeper semicircular and smoothly curved mentum, whereas in $D$. verticulosa the mentum is deep, short and abrupt, forming an acute angle in side view (arrows in Fig. 5C,F, Table 1). Excluding the tails, the new taxon also has larger sepals than what is recorded for $D$. verticulosa. Measurements for $D$. irmelinae were conducted on flowers that developed undisturbed in situ. D. verticulosa is known from abundant material available in cultivation, and while these cultivated plants are characteristically smaller flowered than $D$. irmelinae, there is no data on $D$. verticulosa flower 

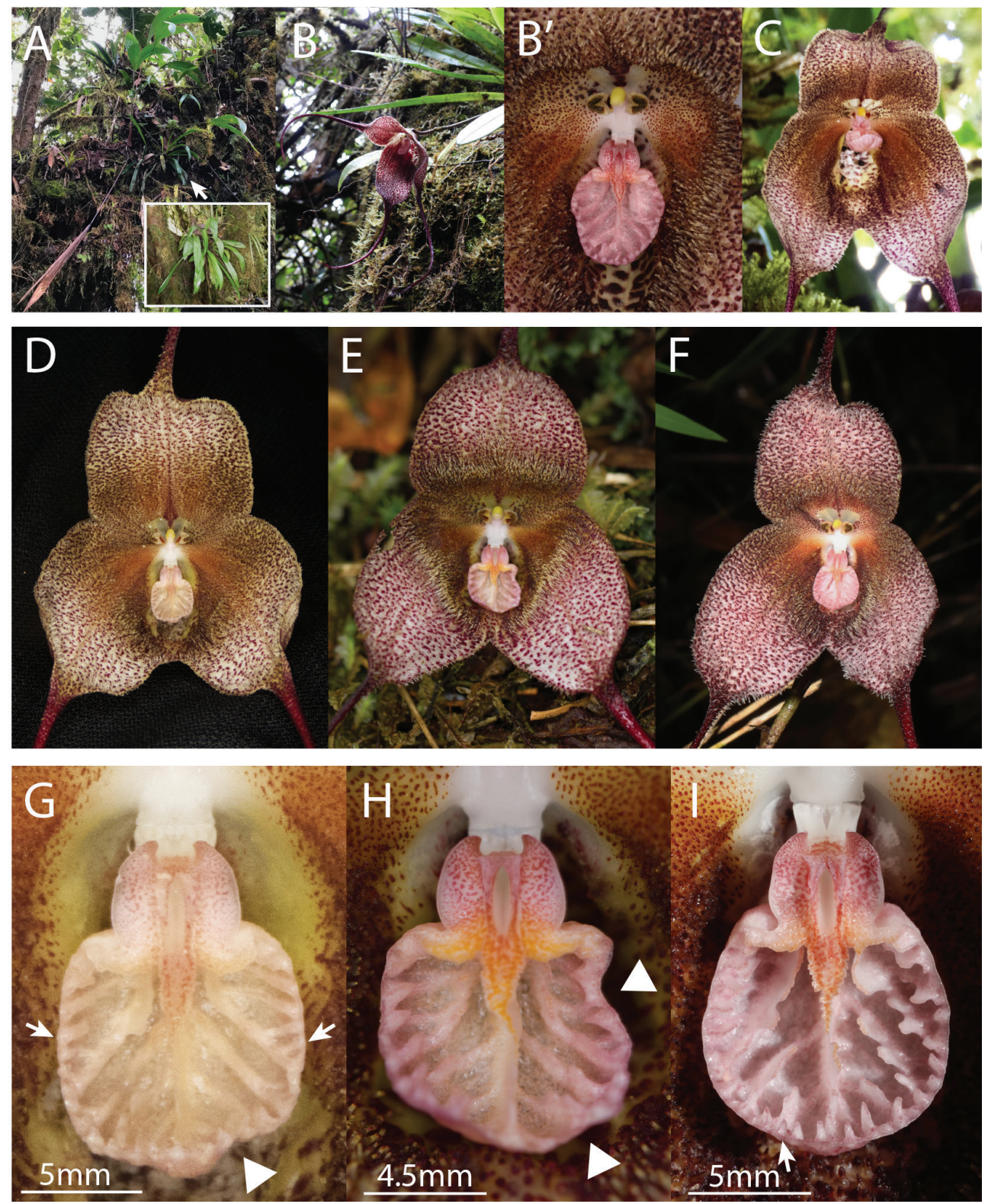

FIgURE 4. Flower visitors and variation of Dracula irmelinae in its native habitat. A. Adult plants of D. irmelinae (arrow) grow on branches covered with moss and drained decaying organic matter. Inset shows a mature plant and seedings. B. Plant and flower used to prepare herbarium specimen (Holotype) in situ. C. Flowers are visited by diurnal flies (Diptera: Drosophilidae). D-F. Natural variation of flower morphology, indumentum pigmentation, sepal width and lip size of $D$. irmelinae in its native habitat (flowers of three mature individuals). G-I. Variation in lip morphology and symmetry. Lip close-ups from flowers (panels D-F) show different lip aspect ratios and fluctuating asymmetry: left and right sides are not symmetric (triangles) and have bilateral differences in secondary carinae branching or in lamellae continuity (arrows). Side illumination of a lip reveals carinas are discontinuous but differ between each side (panel I). Carinae have laminae of variable height that prolong until the edge, creating an internally marginally denticulated lip. The number of teeth can vary between the two sides in some flowers (arrow in panel I). Photographs by N. Peláez (A), L. Mazariegos (B, B', F, I) and G. E. Meyer (C, D,E,G,H, A' inset). 

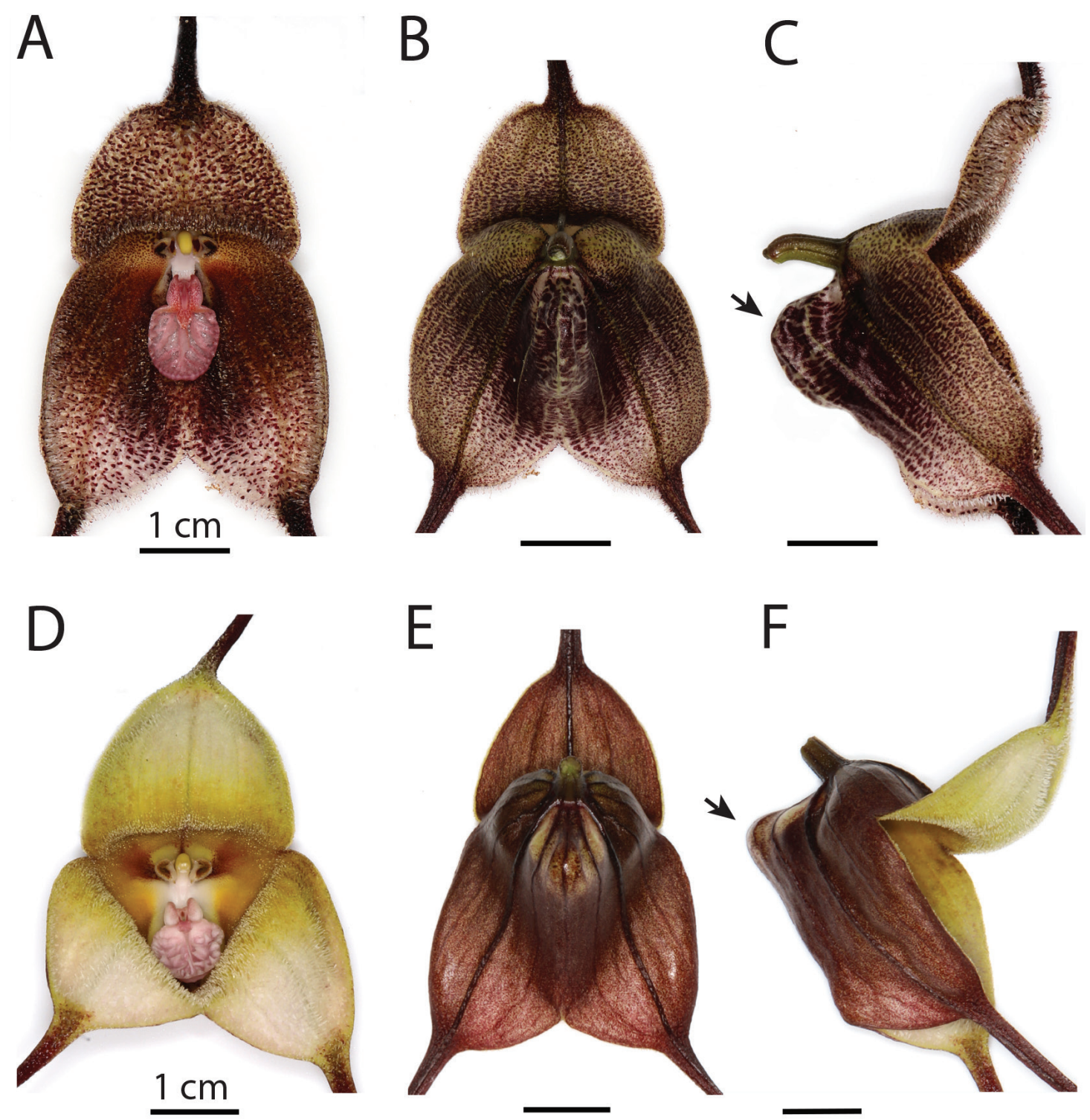

Figure 5. Comparison of the flowers of Dracula irmelinae and D. verticulosa. A-C. Frontal, dorsal and lateral views of the flower of $D$. irmelinae. D-F. Frontal, dorsal and lateral views of the flower of $D$. verticulosa. Note the indumentum of $D$. irmelimae has longer trichomes and dark red to brown maculae internally. A lateral view of the flowers shows the synsepal, created by lateral sepal bases, forms a deep and prolonged semicircular mentum in D. irmelinae and a deeply curved short and abrupt mentum in D. verticulosa. In the former the prolonged mentum is shaped as a long arch whereas in the latter the mentum is acute and short (arrows in panels $\mathrm{C}$ and F, respectively). Photographs by L. Mazariegos.

size in situ. D. verticulosa is reported to grow only at 1800-1900 m a.s.l. (Luer 1993, Luer et al. 1991). In the greenhouses located in the US and Colombia where the species is being maintained, abiotic factors such as temperature, which could affect flower size, usually reach similar temperatures to those predicted to exist in the natural habitat of $D$. verticulosa. As result, it is unlikely that the observed flower size difference between $D$. verticulosa and $D$. irmelinae is an artifact of factors like temperature 
present in ex situ cultivation. Finally, the two species have unambiguously distinct geographic distributions. D. irmelinae occurs $\sim 200 \mathrm{~km}$ further north from $D$. verticulosa, in a different cordillera (see below). The populations of the two species are separated by the Cauca river valley $(\sim 600-900$ $\mathrm{m})$, which acts as a geographic barrier that creates reproductive isolation between the two taxa.

To date D. verticulosa has not been reported in the Western Cordillera of Colombia. Although overall $D$. irmelinae is phenotypically most similar to $D$. verticulosa from the Central Cordillera, when only species of the Western Cordillera are compared, the phenotypically most similar species from the Western cordillera is D. gigas Luer (Luer). The later taxon differs from $D$. irmelinae in that it lacks any significant pubescence or maculate pigmentation in the sepals (vs. densely pubescent sepals), has narrower leaves ( $v s$. broader leaf blades), and thinner, typically erect inflorescences ( $v s$. lateral to usually descending) that do not produce as many flowers per inflorescence. Table 1 compares floral traits and geographic distributions of D. gigas, D. x aphrodes Luer \& Escobar, D. dalströemii Luer, D. $x$ hawleyi Luer, and D. trinympharum Luer with $D$. irmelinae. Within the genus Dracula, these species share some phenotypic similarity with the new taxon described here.

In order to determine if $D$. irmelinae had previously been collected, cultivated and confused with other species such as $D$. verticulosa, the authors studied Dracula in all the commercial Colombian orchid nurseries that amassed large collections prior to the advent of CITES and local prohibitions on wild harvesting of orchids, as well as smaller private collections. No plants matching Dracula irmelinae have ever been observed in these collections by us. However, $D$. verticulosa is frequently and widely represented in these and other nurseries and collections in the USA, Colombia and Ecuador, including specimens that were wild-harvested pre-CITES. No individuals have been observed showing the combination of distinctive pattern of dense long pubescence and maculate red pigmentation on the sepals together with a long and smoothly concave mentum.

Geographic distribution. Prior to the discovery of populations of Dracula irmelinae at the MPNR, the new species had been observed and photographed at least twice as individual plants in the Farallones de Citará, along the mountain ridge of the Western Cordillera in Antioquia. Local nature guides who have explored the Farallones de Citará have provided photographic evidence of two additional distinct populations further north from the MPNR reserve. Additional individuals of the species have been photographed south of the town of Jardín, near a region that had been explored by others since the 1980s (see Luer \& Escobar 1984). The populations studied in the field by us are located at the MPNR, which lies at the southern edge of the Farallones de Citará. Overall, the current data suggests this new taxon is restricted to a small geographic area in the Western Cordillera of Colombia.

The Western and Central Cordilleras of Colombia have long been known to share "pairs" of species that have floral morphological similarity (ie. in sepal, petal and lip shapes). These pairs include Dracula chimaera (Rchb.f) Luer (west) and D. wallisii (Rchb.f.) Luer (central), D. chestertonii (Rchb.f.) Luer (west) and D. cutis-bufonis Luer \& R.Escobar (central), and D. bella (Rchb.f.) Luer (west) and D. nycterina (Rchb.f.) Luer (central). The dark-purple (west) and brown-red (central) forms of D. roezlii can also be considered in this list, even though they are not currently recognized as separate species. There are, of course, species that exist in both cordilleras that do not show significant morphological variation between the two ranges, including D. spectrum and D. trichroma (Schltr.) Hermans (known as D. iricolor (Rchb.f. ex Kraenzl. B) Luer \& R.Escobar by some authors). We propose that $D$. irmelinae and D. verticulosa are additional examples of morphologically similar species that have developed stable distinctions in geographically disjunct populations in the Western and Central Cordilleras of Colombia.

Natural variation. In past decades multiple new Dracula species have been described from one or a few cultivated plants collected in the wild. As a result, natural variation in Dracula populations has remained largely undocumented. Despite $D$. irmelinae being a rare element of the flora at the MPNR, we documented the natural variation observed in situ. The most apparent variation is in flower size and morphology of specific floral structures. Different individuals have flowers 
TABLE 1. Comparison of floral traits and geographic distributions of Dracula species phenotypically similar to D. irmelinae.

\begin{tabular}{|c|c|c|c|c|c|c|}
\hline Species & $\begin{array}{l}\text { Inflorescence } \\
\text { axis orientation }\end{array}$ & $\begin{array}{l}\text { Mentum: } \\
\text { depth, } \\
\text { length } \\
\text { angle } \\
\text { (defined by edges } \\
\text { on a side view) }\end{array}$ & $\begin{array}{l}\text { Internal sepal } \\
\text { indumentum } \\
\text { type and } \\
\text { Sepal color* } \\
\text { (above the middle } \\
\text { halve) }\end{array}$ & $\begin{array}{l}\text { Lip shape } \\
\text { Lip } \\
\text { dimensions }\end{array}$ & $\begin{array}{l}\text { Epichile } \\
\text { shape and } \\
\text { concavity } \\
\text { Hypochile- } \\
\text { epichile } \\
\text { demarcation }\end{array}$ & $\begin{array}{l}\text { Geographic } \\
\text { Distribution }{ }^{\star *} \\
\text { in the Andes }\end{array}$ \\
\hline D. irmelinae & $\begin{array}{c}\text { Usually } \\
\text { descending, } \\
\text { occasionally lateral }\end{array}$ & $\begin{array}{c}\text { Deep, } \\
\text { smoothly curved } \\
\text { and semicircular, } \\
\text { right to obtuse } \\
\text { angle }\end{array}$ & $\begin{array}{l}\text { Dense abundant } \\
\text { long pubescence, } \\
\text { off-white with dark } \\
\text { brown spots }\end{array}$ & $\begin{array}{l}\text { Spatulate, } \\
12 \times 9 \mathrm{~mm}\end{array}$ & $\begin{array}{c}\text { Suborbicular, } \\
\text { concave } \\
\text { clear demarcation }\end{array}$ & $\begin{array}{l}\text { Colombia, Western } \\
\text { Cordillera (Antioquia, } \\
\text { Jardín). }\end{array}$ \\
\hline D. verticulosa & $\begin{array}{c}\text { Usually erect, } \\
\text { occasionally lateral }\end{array}$ & $\begin{array}{c}\text { Deep, } \\
\text { short and abrupt, } \\
\text { acute angle. }\end{array}$ & $\begin{array}{c}\text { Dense short } \\
\text { pubescence, } \\
\text { light yellow } \\
\text { suffused with light } \\
\text { purple }\end{array}$ & $\begin{array}{l}\text { Spatulate, } \\
11 \times 6 \mathrm{~mm}\end{array}$ & $\begin{array}{c}\text { Suborbicular, } \\
\text { concave } \\
\text { clear demarcation }\end{array}$ & $\begin{array}{l}\text { Colombia, Central } \\
\text { Cordillera (Valle del } \\
\text { Cauca, near Costa } \\
\text { Rica and Ginebra) }\end{array}$ \\
\hline $\begin{array}{l}\text { D. } \boldsymbol{x} \text { aphrodes } \\
\text { (probably hybrid } \\
\text { between } D . \\
\text { verticulosa and } D . \\
\text { insolita) }\end{array}$ & Erect & $\begin{array}{c}\text { Shallow, } \\
\text { semicircular and } \\
\text { prolonged, } \\
\text { obtuse angle }\end{array}$ & $\begin{array}{c}\text { Glabrous, } \\
\text { lightly suffused } \\
\text { with pale purple }\end{array}$ & $\begin{array}{l}\text { Pandurate, } \\
13 \times 6 \mathrm{~mm}\end{array}$ & $\begin{array}{l}\text { Oblong, } \\
\text { shallowly concave } \\
\text { clear demarcation }\end{array}$ & $\begin{array}{l}\text { Colombia, Central } \\
\text { Cordillera (Valle del } \\
\text { Cauca, near Costa } \\
\text { Rica and Ginebra) }\end{array}$ \\
\hline D. gigas & $\begin{array}{c}\text { Usually erect, } \\
\text { occasionally lateral }\end{array}$ & $\begin{array}{c}\text { Deep, } \\
\text { short and abrupt, } \\
\text { acute angle. }\end{array}$ & $\begin{array}{l}\text { Glabrous, } \\
\text { light pinkish } \\
\text { brown (dull yellow } \\
\text { with numerous } \\
\text { minute purple } \\
\text { brown dots) }\end{array}$ & $\begin{array}{l}\text { Spatulate, } \\
10 \times 6 \mathrm{~mm}\end{array}$ & $\begin{array}{c}\text { Suborbicular, } \\
\text { concave } \\
\text { clear demarcation }\end{array}$ & $\begin{array}{l}\text { Colombia, Western } \\
\text { and Central } \\
\text { Cordilleras (Valle del } \\
\text { Cauca) Northern } \\
\text { Ecuador (Carchi, } \\
\text { Maldonado) }\end{array}$ \\
\hline D. dalströemii & Erect & $\begin{array}{c}\text { Deep, } \\
\text { short and abrupt, } \\
\text { acute angle }\end{array}$ & $\begin{array}{c}\text { Diffusely } \\
\text { pubescent } \\
\text { with very short } \\
\text { trichomes, } \\
\text { creamy white } \\
\text { suffused with light } \\
\text { brown small spots }\end{array}$ & $\begin{array}{l}\text { Spatulate, } \\
8.5 \times 6 \mathrm{~mm}\end{array}$ & $\begin{array}{c}\text { Suborbicular, } \\
\text { concave, } \\
\text { clear demarcation }\end{array}$ & $\begin{array}{l}\text { Northern Ecuador } \\
\text { (Carchi, Maldonado) }\end{array}$ \\
\hline $\begin{array}{l}\text { D. } x \text { hawleyi } \\
\text { (probably hybrid } \\
\text { between D. gigas } \\
\text { and D. levii) }\end{array}$ & Erect & $\begin{array}{l}\text { Shallow to } \\
\text { almost absent, } \\
\text { short, } \\
\text { obtuse angle }\end{array}$ & $\begin{array}{l}\text { Glabrous, } \\
\text { yellowish-white } \\
\text { suffused with light } \\
\text { orange-brown } \\
\text { spots }\end{array}$ & $\begin{array}{c}\text { Spatulate, } \\
8.5 \times 5 \mathrm{~mm}\end{array}$ & $\begin{array}{l}\text { Suborbicular, } \\
\text { Shallowly } \\
\text { concave } \\
\text { indistinct } \\
\text { demarcation }\end{array}$ & $\begin{array}{l}\text { Northern Ecuador } \\
\text { (Carchi, Maldonado) }\end{array}$ \\
\hline D. trinympharum & Erect & $\begin{array}{c}\text { Shallow, } \\
\text { short, } \\
\text { right angle }\end{array}$ & $\begin{array}{c}\text { Glabrous, } \\
\text { yellowish-white, } \\
\text { composed of } \\
\text { small red papillae }\end{array}$ & $\begin{array}{l}\text { Obscurely } \\
\text { pandurate, } \\
7 \times 4 \mathrm{~mm}\end{array}$ & $\begin{array}{c}\text { Suborbicular, } \\
\text { deeply concave, } \\
\text { indistinct } \\
\text { demarcation }\end{array}$ & $\begin{array}{l}\text { Northern Ecuador } \\
\text { (Carchi, Maldonado) }\end{array}$ \\
\hline
\end{tabular}

* Pale xanthic flower coloration triggered by recessive alleles has been documented for $D$. verticulosa and $D$. gigas and several other Draculas and might exist for all the Dracula species in these table. Our color description here refers only to the wild type (non-xanthic) color forms.

** Geographic distributions and traits in this table have been derived from botanical illustrations, pictures and/or herbarium specimens from Luer (1993), as well as from additional observations made by the authors.

with significantly wider or longer sepaline cups and broader sepals (compare Fig. 4, panels D vs. E-F). The lip shows morphological variation in its length-to-width aspect ratios, as well as in its overall size relative to the sepals (Fig. 4B', G-I). Also, within some individual flowers the right and left sides are not mirror images of each other and have fluctuating asymmetry (FA). FA has been documented in many plants and animals (Graham et al. 1993, Donguen 2006). In the flowers of D. irmelinae FA exists in the position and size of spots in the indumentum of the sepals and between the right and left sides of the lip. Specifically, the overall epichile 
shape (triangles in Fig. 4G-I), the carinae branching pattern, the continuity of the lamellae and the number of marginal teeth present at the end of carinae (arrows in Fig. 4G-I) are asymmetric across the two halves of the labellum in some flowers. Given that so far only a small number of flowers have been found in situ ( $\mathrm{n}=17$ from different adult individuals), no quantitative analysis of asymmetry or phenotypic variation across individuals is currently feasible. It is unknown if there is lip directional asymmetry (sensu Graham et al. 2010) at the population level. The developmental or environmental causes of flower asymmetries, their possible role in pollination and the evolutionary origin of the phenotypic variation observed across individuals in natural populations of $D$. irmelinae remain unknown. However, the overall flower pigmentation pattern created by an indumentum in the sepals containing dark red maculae internally and externally, the dense long pubescence on the internal distal sepal surfaces and bases of tails, and the deep, prolonged and smoothly curved mentum have been observed in all individuals examined so far. Therefore, these traits constitute a set of diagnostic characters that distinguish $D$. irmelinae from $D$. verticulosa and D. gigas.

Hybrid origin or past introgression with other species of Dracula has been proposed to explain morphological or genetic similarity at the DNA sequence level between different species of the genus (Cameron \& Meyer 2009). Although D. irmelinae has been found growing in the same phorophytes with other Dracula species (data not shown), no intermediate forms between the different species other than D. irmelinae have been found so far at the MPNR. Also, no intermediate forms between $D$. irmelinae and the other taxa present at the preserve have been discovered in the forest. These findings make unlikely past or recent hybridization or introgression between D. irmelinae and other species. However, molecular studies are required to determine if hybridization could be responsible for the observed variation present in the populations located at the MPNR.

Phylogenetic relationships. As the holotype and paratypes represent the first material collected for this species, phylogenetic analysis including the taxon have not been conducted yet. Further, the work of Cameron and Meyer (2009) using a panel of common plastid and nuclear markers on over $95 \%$ of the known Dracula species found low phylogenetic signals among the majority of species in the DNA sequences investigated. The candidate sister species, which would share the most immediate common ancestor with $D$. irmelinae, is hypothesized to be $D$. verticulosa. However, in the current phylogenies, the latter taxon lies in part of the polytomy with other poorly resolved taxa. Doucette and Cameron have had success resolving a sub-portion of the genus corresponding to the Central American Draculas using SNP technology (Doucette, pers. com. 2018). Future studies using cultivated material of the new species, and more advanced molecular approaches using genomics will be required to establish a new phylogeny of Dracula and the position of this new taxon within it.

Conservation status. Dracula irmelinae has apparently escaped discovery in a region of Colombia that has been scoured for Dracula orchids since the time of the Victorian orchid craze. This is possibly due to it being endemic to a small area in the Western Cordillera of Colombia. Also, this region had been dangerous to visit for several decades during the height of the Colombian armed conflict, and is only recently opening to re-exploration, and potential poaching. Promising habitat for this species exists throughout the heights of the Farallones de Citará. However, agriculture encroaching from the heavily deforested Cauca River Valley, rampant illegal mining and poaching, as well as more recent attempts to develop legal mining projects in the Western Cordillera, all threaten precious cloud forest habitats that the armed conflict indirectly kept safe.

Although Dracula irmelinae has been documented in other localities outside the MPNR, the total known estimated Area of Occupancy (AO), including the remaining forests near Jardin, Farallones del Citará and MPNR, does not exceed $500 \mathrm{~km}^{2}$. In addition to the small AO, two other criteria are met. First, although individuals of this species have been found at other sites in the Farallones de Citará, current data suggest the number of locations is still less than 5 and/or might be fragmented in part of the species distribution range (criterion a). Second, the forest suitable for the species is located at a narrow altitudinal range, and due to expansion of the agricultural frontier and forest 
fragmentation, possible future mining, and continued illegal orchid collecting in the area, we infer a possible continuing decline in the (i) extent of occurrence, (ii) area of occupancy, (iii) area, extent and/or quality of habitat, (iv) number of locations or subpopulations, and (v) number of mature individuals of this taxon. We therefore propose the new species should be considered Endangered (EN) according to the International Union for Conservation of Nature Red List criterion B2 (IUCN 2017) and we characterize the status of this new species as EN, B2ab (i,ii,iii,iv,v).

\section{Biodiversity conservation at the Mesenia-} Paramillo Nature Reserve (MPNR). The MPNR has contributed to the description of several new species of plants and animals. Although Dracula irmelinae had been photographed outside the MPNR, the presence of the reserve allowed a detail study of the populations, which ultimately resulted in the description of this new taxon. The MPNR will allow conserving populations of this new species. The authors want to highlight the importance of preserving the forests contained within the MPNR and surrounding areas, since they constitute a highly biodiverse region hosting other orchid species currently categorized as critically endangered (CR), endangered (EN) and vulnerable (VU) according to IUCN criteria. These taxa include other species of Dracula and Masdevallia.

ACKNOWLEDGMENTS. The authors want to thank Leonardo DiCaprio and SavingNature (https://savingnature.com previously known as SavingSpecies) for their financial support, which has helped maintain and expand the preserve where this new Dracula species was discovered and is being conserved. The authors also owe gratitude to the late Gustavo A. Suarez Osorio, who died recently while this study was on its way. Gustavo, an exceptional naturalist, worked with The Hummingbird Conservancy to establish the preserve that will allow conservation of this new orchid species, and participated in the field work that led to its discovery. We thank two anonymous reviewers for their comments. Nicolás Peláez thanks the California Institute of Technology for institutional support and The Howard Hughes Medical Institute (HHMI) and the Hanna H. Gray Fellows Program for funding and institutional support. The authors thank Elsy C. Buitrago-Delgado for a critical review of the manuscript, Juan Felipe Posada and the Posada family (Colomborquídeas Ltda) for providing us with living material of Dracula verticulosa used for comparison and Autoridad Nacional de Licencias Ambientales (ANLA) for granting scientific survey collection permits (resolution $\mathrm{N}^{\circ}$ 01711, 30 ${ }^{\text {th }}$ December, 2016) used for the collection of wild specimens for this publication.

\section{Literature Cited}

Averyanov, L. V., The, P. V., Ke, L. P., Tien, H. N., Xuan, C. C., Tien, V. N. \& Quang, H. N. (2014). Field survey of Paphiopediulum canhii: from discovery to extinction. Retrieved from: https://www.rufford.org/files/www.slipperorchid. org_0.pdf Accessed on 10-13-2019.

Baquero, L. E. R. (2013). Dracula marinii Baquero, A recently discovered Ecuadorian species of orchid in the Pleurothallidinae (Orchidaceae). Orquideología, 30(2), 67.

Baquero L. E. R. \& Meyer G. (2014). Dracula smang, Baquero \& Gary Mey., A recently discovered Ecuadorian species of orchid in the Pleurothallidinae (Orchidaceae). Orquideología, 31(2), 86.

Cavestro, W. \& Fernandez, J. (2016). Dracula marieae: une nouvelle espèce du nord de l'Équateur. L'Orchidophile, 47, $57-64$.

Calderón, E., Farfán, J., Constantino, E. \& Peláez, N. (2006). Fichas Técnicas de Categorización - Géneros Anguloa, Cattleya, Coeliopsis, Comparettia, Coryanthes, Cycnoches, Dracula, Embreea, Lycaste, Masdevallia, Miltoniopsis, Odontoglossum, Otoglossum, Phragmipedium, Psychopsis, Restrepia, Rodriguezia y Selenipedium. En E. CalderónSáenz (ed.), Libro Rojo de Plantas de Colombia. Volumen 3: Orquídeas, Primera Parte (pp. 57-584). Serie Libros Rojos de Especies Amenazadas de Colombia. Bogotá, Colombia: Instituto Alexander von Humboldt - Ministerio de Ambiente, Vivienda y Desarrollo Territorial. 828 p.

Cameron, K. M. \& Meyer, G. F. (2009). A preliminary phylogenetic study of Dracula (Pleuropthalidinae, Epidendroidae, Orchidaceae) based on plastid matK sequence data. In J. T. Otero, A. M. Pridgeon \& J. P. Suárez (Eds.), Proceedings of the Second Scientific Conference on Andean Orchids (pp. 100 -114). Loja, Ecuador: Universidad Tecnológica Particular de Loja.

Doucette, A. (2011). Dracula immunda (Orchidaceae: Pleurothallidinae), a new species from Panama. Phytotaxa, 16, 37-44.

Doucette, A. (2012a). Dracula agnosia (Orchidaceae: Pleurothallidinae), a long confused undescribed species. Phytotaxa, $56,23-27$. 
Doucette, A. (2012b). Validation of Dracula trignopetala (Orchidaceae: Pleurothallidinae) with an English diagnosis and description. Phytotaxa, 74, 59.

Dongen, S. V. (2006). Fluctuating asymmetry and developmental instability in evolutionary biology: past, present and future. Journal of Evolutionary Biology, 19(6), 1727-1743.

Endara, L., Grimaldi, D., Roy, B. A. (2010). Lord of the flies: pollination of Dracula orchids, Lankesteriana, 10(1), 1-11.

Graham, J. H., Freeman, C. D., Emlen, J. (1993). Antisymetry, directional asymmetry and dynamic morphogenesis. Genetica, 89, 121137.

Graham, J. H., Raz S., Hel-Or H. \& Nevo E. (2010). Fluctuating Asymmetry: Methods, Theory, and Applications. Symmetry, 2(2), 466-540.

IUCN Standards and Petitions Subcommittee. (2017). Guidelines for Using the IUCN Red List Categories and Criteria. Version 13. Prepared by the Standards and Petitions Subcommittee in March 2017. Retrieved from https://www. iucnredlist.org/resources/redlistguidelines. Accessed on 01-10-2018.

Karremans, A. P. (2016). Genera Pleurothallidinarum: an updated phylogenetic overview of Pleurothallidinae. Lankesteriana, 16(2), 219-241.

Luer, C. A. (1993). Icones Pleurothallidinarum X. Systematics of Dracula. Monographs in Systematic Botany from the Missouri Botanical Garden, 46, 1-244.

Luer, C. A. \& Escobar, R. (1984). New species of Pleurothallidinae from Colombia (Masdevallia hortensis Luer \& R.Escobar). Oquideología, 16(2), 154-157.

Luer, C. A. \& Thoerle, L. (2012). Miscellaneous new species in the Pleurothallidinae (Orchidaceae). Harvard Papers in Botany, 17(2), 333-368.

Luer, C. A., Escobar R., R. \& Dalström, S. (1988). Thesaurus Dracularum, A monograph of the genus Dracula, Volume I. St. Louis: Missouri Botanical Garden.

Luer, C. A., Escobar R., R. \& Dalström, S. (1989). Thesaurus Dracularum, A monograph of the genus Dracula, Volume II. St. Louis: Missouri Botanical Garden.

Luer, C. A., Escobar R., R. \& Dalström, S. (1990). Thesaurus Dracularum, A monograph of the genus Dracula, Volume III. St. Louis: Missouri Botanical Garden.

Luer, C. A., Escobar R., R. \& Dalström, S. (1991). Thesaurus Dracularum, A monograph of the genus Dracula, Volume IV. St. Louis: Missouri Botanical Garden.

Luer, C. A., Escobar R., R. \& Dalström, S. (1992). Thesaurus Dracularum, A monograph of the genus Dracula, Volume V. St. Louis: Missouri Botanical Garden.

Luer, C. A., Escobar R., R. \& Dalström, S. (1993). Thesaurus Dracularum, A monograph of the genus Dracula, Volume VI. St. Louis: Missouri Botanical Garden.

Luer, C. A., Escobar R., R. \& Dalström, S. (1994). Thesaurus Dracularum, A monograph of the genus Dracula, Volume VII. St. Louis: Missouri Botanical Garden.

Meyer, G. E., Baquero, L. \& Cameron, K. M. (2012). A new Ecuadorian species of Dracula: Pleurothallidinae (Orchidaceae). Orchideen Journal, 19, 107-113.

Peláez, N., Buitrago-Delgado, E., Meyer, G. (2009). New Colombian species of Dracula and Masdevallia: Pleurothallidinae (Orchidaceae). Orquideologia, 26 (1), 25-45.

Policha, T., Davis, A., Barnadas, M., Dentinger, B. T. M., Raguso, R. A. \& Roy, B. A. (2016). Disentangling visual and olfactory signals in mushroom-mimicking Dracula orchids using realistic three-dimensional printed flowers. New Phytologist, 210, 1058-1071.

Policha, T., Grimaldi, A. D., Manobanda, R., Troya, A., Ludden, A., Dentinger, B. T. M. \& Roy, B. A. (2019). Dracula orchids exploit guilds of fungus visiting flies: new perspectives on a mushroom mimic. Ecological Entomology, 44, 457-470.

Zambrano, B. J. \& Solano-Gómez, R. (2011). A new natural hybrid of Dracula (Orchidaceae: Pleurothallidinae) from southwestern Ecuador. Revista Mexicana de Biodiversidad, 82, 758-761 
